\title{
Determinants of non-performing loans in state-owned banks
}

\author{
Renno Prawira*, Sudarso Kaderi Wiryono \\ School of Business and Management, Bandung Institute of Technology, Bandung, Indonesia \\ ${ }^{*}$ Corresponding author email: renno-prawira@sbm-itb.ac.id
}

A R T I C LE IN F O

Article history:

Available online

Keywords:

Banking factors, Non-Performing

Loans (NPLs), state-owned banks,

Indonesia

DOI:

https://doi.org/10.20885/jaai.vol24.i

ss2.art9

\section{A B S T R A C T}

The increase in NPLs has been shown to have a negative impact on banking sector, so it is highly necessary to consider the determinants of NPLs to ensure the overall economy's effectiveness and soundness. This study aims to shed light on bank-specific factors affecting NPLs in Indonesia whose banking sector has crucial impacts on the overall economy. The data involved 35 state-owned banks (conventional, Islamic, and regional banks) throughout 2010-2019. The banking factors in this study include bank efficiency, profitability, income diversification, and capital adequacy. Random and fixed effects regression model was used to make the estimates. The results showed that the bank efficiency variable positively correlated with NPLs, but the profitability variable correlated negatively. Both variables were significant statistically, while income diversification and bank capital variables were insignificant statistically. Based on this study, we suggest that the government require banks to have adequate profit. Thus, banks are able to run the good credit management process which will finally decrease the NPLs in the banks.

\section{Introduction}

One of the most urgent problems for banking sector is financial crisis. In the last few years, grave financial crises were experienced globally. Because of the financial credit crises in 2007 and 2008, a financial crisis has recently been encountered in the U.S. subprime mortgages. In 1997, East Asian countries experienced a financial crisis in the form of massive capital outflows of the foreign investors (Soedarmono et al., 2011). One of the financial crisis characteristics is increasing number of Non-Performing Loans (NPLs) in banking industry. Following the global financial crisis, NPLs are the main issue in banking management and government as NPLs are regarded as a collapse of the banking industry (Ghosh, 2015). It is obvious phenomena for the countries that depend on banks as financial intermediaries that transfer money across the world's economy.

Loans that remain outstanding are defined as NPLs. The World Bank suggests that if loans do not generate the principal amount and interest for 90 days, they will be called as NPLs. Alton and Hazen (2001) note that loans become NPLs because their interests and principal amount are not yet paid on the maturity dates and are not anticipated for the future dates. Low-capacity credit specialists, poor credit processes, lack of policies controlling borrowers, low credit principles, and high markup range are the key reasons for high number of NPLs. NPL is the major indicator of financial risk measurement that affect the banking industry. Ivanovic (2016) emphasizes that the predictors of financial crises should adopt NPLs which affect the nation's economic growth through credit lending. A low NPL level indicates a country's strong monetary system, whereas higher level of NPLs suggests a poor monetary condition. In the long run, Souza and Feijó (2011) explains that the growing NPLs level should first affect the commercial banks and then impact the country's financial status. Vouldis and Louzis (2018) note that the bunch of NPLs should disturb a banking system's effectiveness which may result in a financial crisis. The number of NPLs would cut off the financial opportunities, interest income, and financial system liquidity growth resulting in bankruptcy and flawed economic system. Therefore, Stijepović (2014) emphasized that the factors influencing NPLs needed to be reduced to decline the NPLs' level for economic stability and financial strength.

The impact of NPLs in the banking sector is a comprehensive routine and thus threatens the banking sector bankruptcy (Michael et al., 2006). Berger and DeYoung (1997) note that high NPL level directly influences banks' overall financial performance. Nkusu (2011) notes that banks' high NPL level is the main determinant of the macroeconomic vulnerabilities in advanced countries. State-owned banks have a crucial role in Indonesia because they manage almost half the assets of the banking sector. As a financial institution operated under Indonesia's government, state-owned banks serve as a collaborator of the government in economic activities such as microcredit and public finance (Prasanto et al., 2020). This study observed 35 state-owned banks (26 regional banks, four commercial banks, and five Islamic banks) during 2010-2019. 


\section{Literature Review}

Khan et al. (2020) identify numerous banking factors affecting the level of NPL, namely bank efficiency, Return on Asset (ROA), income diversification, and Capital Adequacy Ratio (CAR). However, the relationship between NPL and those variables is not yet clear. Some researchers concluded that there were positive correlations between these variables. On the other hand, others denied the findings.

\section{Bank Efficiency}

If a bank displays all its commercial businesses at a comparatively low cost, it can be concluded that the bank is efficient. Berger and DeYoung (1997) stated that a reduction in U.S. commercial banks' cost-effectiveness would impact the rise in potential loan losses. The condition is suffered by those managers who cannot monitor the operating expenses and manage the loan portfolio. It is supported by the skimping hypothesis which states that if banks determine to allocate less on loan operating underwriting and monitoring in the short term, in the long run, NPLs will increase.

In another analysis, cost efficiency rise is accompanied by a slog of loan defaults in the efficient banks. Ekanayake and Azeez (2015) analyzed various elements affecting NPL level in Sri Lanka's financial sector from 1999 to 2012 and concluded that NPLs positively correlate with the bank size and bank efficiency. There are correlations between NPL level in private banks and their banking factors such as capitalization, bank efficiency, and profitability. The finding showed that bank efficiency led to high NPL level, indicating that the managements influenced NPL level. Fiordelisi et al. (2011) analyzed numerous determinants affecting bank bankruptcy level in E.U. banks then predicted that, in the future, declining efficiency would increase banks' risk levels. Therefore, the hypothesis will be formulated as follows.

H1. Bank efficiency negatively correlates with NPLs level.

\section{Return on Assets (ROA)}

The relationship between Return on Assets (ROA) and NPL was investigated by Tanda (2015) who reported that the smaller the ROA level, the greater the NPL level and vice versa. Boudriga et al. (2009) found that ROA and NPLs had negative relationship. They concluded that the bank continued to proceed with high-risk investments when the ROA decreased, resulting in increase in NPLs. Makri et al. (2014) assumed that there was a negative correlation between NPLs and ROA.

On the other hand, Ahmad and Bashir (2013) said that there was a positive correlation between NPLs and ROA. Banks with higher income levels are less interested in riskier projects that could contribute to potential loan non-payment (Berger \& DeYoung, 1997) Another study concludes a negative correlation between NPL level and ROA is the research by Rajan (1994) which claima that the purpose of loan policy is not only to create income, but also to create goodwill; so, bank management aims to build a strong current earnings credit strategy to offset loan losses in the next cycle. It thus allows a positive correlation between NPL level and ROA. Based on the previous argument, the hypothesis is structured as follows.

H2: ROA positively correlates with NPL level.

\section{Income Diversification}

Banks produce two kinds of earnings: one from lending activities and non-interest activities: and, the other from derivative and trading transactions. Banks with more income than interest income will be more prudent to invest in high-risk projects and will attempt to lower their risks. Those banks get much better loan performance, illustrating the reverse correlation of income diversification and NPL level (Ghosh, 2015). However, Hu et al. (2004) mentioned that there was no relation between income diversification and NPL level. Louzis et al. (2012) studied different bank sectors and microeconomic variables of NPL factors like ROA, leverage ratio, non-interest revenue, and CAR in various Greek banks. They assumed that ROA had a negative effect, although non-interest sales positively influenced NPL level. Rachman et al. (2018) analyzed the numerous banking determinants that influenced Indonesia's NPL level, namely bank capital, income diversification, and other banking determinants. The analysis showed that these variables had little effects on NPL level; however, income diversification negatively correlated with NPLs. Considering the previous findings mentioned above, the hypothesis proposed is as follows.

H3: Income diversification positively correlates with NPLs

\section{Bank Capital}

Bank capital impact on the level of NPL goes in an adverse direction. On the one hand, incentives and rewards from small-capitalized banks involve themselves in higher-risk projects and give credit without an appropriate credit rating and supervision (Keeton, 1999). Because of this tradition, there is an increase in loan loss, explaining a 
negative relationship between bank capital rate and NPL level. On the other hand, banks with strong bank capital rates prefer to deliver a loan conveniently because the managements think that banks would not be bankrupt and fail because of these loans; thus, banks are deeply involved in the practice of doubtful loan activities that indicate a positive relationship between NPLs and bank capital (Rajan, 1994)

The measurement of a bank's capacity to meet and overcome unusual default is the capital adequacy ratio (CAR). Hu et al. (2004) described that bank capital negatively affected NPL level when banks offered risky advances. Makri et al. (2014) also reported that CAR and NPLs have a negative correlation.However, Djiogap and Ngomsi (2012) revealed that both CAR rate and NPL level were positively related. Mensah and Adjei (2015) analyzed the numerous bank determinants affecting Ghana's NPL level and mentioned that although bank capital positively affected NPLs, microeconomic conditions negatively affected NPLs. Kumar and Kishore (2019) also reported that NPL level and CAR rate negatively affected banking institution concerning banking factors. Koju et al. (2018) conducted a study into Nepal's banking institution and found that CAR rate was negatively related to NPLs. Considering the diversity of opinions and controversy among researchers, the hypothesis of this study will be formulated as follows.

H4. CAR rate positively correlated with NPLs level.

\section{Research Method}

The data were derived from 35 state-owned banks' balance sheets and income statements ( 26 regional banks, four commercial banks, and five Islamic banks). Three different types of banks (regional, conventional, and Islamic) were used for study during the period ranging from 2010-2019. This time was taken since the estimation of NPL level in Indonesia's banking industry was never considered in the previous studies. The period started in 2010 because there was a financial crisis in 2008, and some Islamic state-owned banks were just established in 2010. Prior studies had observed similar topic for the period from 2008 to 2015 focusing on commercial banks by Rachman et al. (2018). The studies on assessing NPLs considering types of banks are lacking. In this study, the dependent variable was described as NPL level and examined as net NPLs, while bank efficiency, profitability, income diversification, and bank capital were described as independent variables. To control the model, total assets and listed banks were used as control variables.

\section{Variable Explanations}

\section{Non-Performing Loans (NPLs)}

The determinant of this model is NPLs. Loans that remain unpaid are called NPLs. The International Monetary Fund claims that a loan is described as an NPL if it does not set up the principal amount and interest rates during 90 days. Alton and Hazen (2001) suggest that loans transform into NPLs if the interest's full payment and principal amount are not made on the maturity date and not predicted on future dates. In this analysis, NPLs were calculated as net NPLs. Prasanna et al. (2014) describe that net NPLs are more accurate to calculate actual loans rather than gross NPLs. Net NPLs are calculated gross NPLs subtracted by bank provision.

\section{Bank Efficiency}

Bank efficiency could be described as the cost function affecting banks' income rise, or it is not about rising income, but rather about reducing costs at production levels (Daley \& Matthews, 2009). Also, it is determined as a noninterest expense divided by non-interest income.

\section{Return on Asset (ROA)}

ROA is measured to calculate bank profitability and calculated as the net income to total assets (Rajan, 1994). Strong ROA reveals the bank stability in financial position, so the bank tends to invest in safety investments due to less stress to generate return.

\section{Income Diversification}

Banks generate income from the sources other than interest earnings which are called income diversification, which is calculated as non-interest earnings divided by total income (Louzis et al., 2012).

\section{Bank Capital}

CAR calculates bank level of soundness. It reflects bank ability to stand up in unexpected losses and demonstrates bank power and stability in crisis times. For their survival, banks should manage the minimum of CAR. The ratio of total equity to total assets is calculated as CAR (Makri et al., 2014). 


\section{Control Variable}

The control variables of this study were bank size, listed banks, and regional banks. Bank size was calculated by total assets. The total assets (TA) calculated the total nominal amount of bank activities in trillion rupiahs. Meanwhile, dummy variables was used for listed banks (LB), in which 1 meant listed banks and 0 otherwise. Similarly, regional banks (RB) employed dummy variables where 1 meant regional banks and 0 otherwise.

To analyze the results, STATA statistical software was used. Various models are available to analyze the data, like the common effect panel least square model, random effect panel least square model, and fixed effect panel least square model. One of the easiest techniques to disregard the influence of single bank and time is a common effect model, assuming that entirely banks are homogeneous and that their presence over time is the same. Therefore, the common effect least square model has the same constants and coefficients across individual banks and overtime cycles.

$Y_{t}=a+\beta X_{t}+\epsilon_{t}$

The fixed effect least square model is calculated by manipulating over period unidentified heterogeneity and permitting the variation behavior between individual banks. Therefore, the model permits constants differently for individual banks, but the coefficients are fixed along the period.

$Y_{i t}=a+\beta X_{i t}+\epsilon_{i t}$

The random effect least square model is calculated by permitting the individual banks to differ in time (Gujarati \& Dawan, 2015). Therefore, the random effect panel least square model's coefficients are fixed, and a random component consists of a constant in the random effect.

$Y_{i t}=a+\epsilon+\beta X_{i t}+\epsilon_{i t+} \Theta_{i t}$

The relationships among different independent variables in panel regression and NPLs were examined in this study. As the panel regression contains time series and cross-sections, the residuals are likely to interact with individual banks and time, so, the model is biased.

The banking factors model equation is as follows.

$$
\mathrm{NPL}_{i t}=\beta_{0}+\beta_{1} B E F_{i t_{+}} \beta_{2} R O A_{i t}+\beta_{3} D I V_{i t}+\beta_{4} C A R_{i t}+\beta_{5} T A_{i t} \beta_{6} L B_{i t} \beta_{7} R B_{i t} \epsilon_{i t}
$$

Where NPL $i t$ denotes the net NPL banks for a bank I in the period t. $\beta_{0}$ expresses the intercept. $B E_{i t}$ defines bank efficiency of the individual banks in the period t. $R O A_{i t}$ shows the bank profitability of the individual banks in the period t. $D I V_{i t}$ describes the bank income diversification of the individual bank for the period t, $C A R_{i t}$ describes the bank capital for a bank I in the period t. $T A_{i t}$ describes the control variable for total assets of a bank I in the period t. $L B_{i t}$ describes the control variable for listed banks of a bank I in the period t, and $R B_{i t}$ describes the control variable for regional banks of a bank I in the period t. $t$ expresses the period from 2010 to 2019, and I expresses the banks. Moreover, $\beta 1, \beta 2, \beta 3, \beta 4, \beta 5, \beta 6$, and $\beta 7$ express respective coefficients.

\section{Results and Discussion}

\section{Descriptive Analysis}

This stage shows the descriptive analysis of dependent, independent, and control variables. NPLs, bank efficiency, ROA, income diversification, bank capital, total assets, and listed banks were gathered from the state-owned banks over the period 2010-2019 from Indonesian Financial Service (OJK).

The total number of observations was 350 in this study. Table 1 describes that the mean scores of NPL, bank efficiency ratio, bank profitability, bank income diversification, bank capital, total assets, and listed banks were $1.14,76.16,2.61,0.11,19.56,86.96$, and 0.2 respectively. With the minimum NPL score -1.8 and the maximum score 6.77, the standard deviation of bank NPL was 1.2. The maximum score of bank efficiency was 76.16; the minimum score was 0.65 , and the standard deviation was 12.82 . Also, the standard deviation of Return on Asset was 1.4, with the minimum score -8.09 and the maximum score 7.44. The maximum and minimum scores were 1.10 and 0.20 respectively for variable income diversification, with a standard deviation of 0.12 . For bank capital, 9.57 and 35.47 were the minimum and maximum scores severally, with a standard deviation of 4.64. Control variables consisted of total assets, listed banks, and regional banks with each corresponding maximum scores $1343.078,1$, and 1 respectively, and the minimum scores 1.14, 0 , and 0 sequentially. The standard deviation for the control variables were $222.79,0.4$, and 0.43 . 
Table 1. Descriptive statistics of all variables

\begin{tabular}{lrrrrrrrr}
\hline Variable & NPL & \multicolumn{1}{l}{ BEF } & ROA & DIV & & CAR & TA & \multicolumn{2}{c}{ LB } & RB \\
\hline Mean & 1.1 & 76.16 & 2.6 & 0.11 & 19.56 & 86.96 & 0.20 & 0.74 \\
Maximum & 6.7 & 134.63 & 7.44 & 1.1 & 35.47 & 1343.078 & 1 & 1 \\
Minimum & -1.8 & 0.65 & -8.09 & 0.02 & 9.57 & 1.14 & 0 & 0 \\
Standard deviation & 1.2 & 12.82 & 1.4 & 0.12 & 4.64 & 222.79 & 0.40 & 0.43 \\
Number of observations & 350 & 350 & 350 & 350 & 350 & 350 & 350 & 350 \\
\hline
\end{tabular}

\section{Correlation Table}

The correlation table between the independent and dependent variables is demonstrated in Table 2. There was no multicollinearity issue between independent and dependent variables since the scores of both variables were below 0.80 .

Table 2. Correlation all variables

\begin{tabular}{lrrrrrrrr}
\hline Variable & NPL & BEF & ROA & DIV & CAR & TA & LB & RB \\
\hline NPL & 1 & & & & & & & \\
BEF & 0.5267 & 1 & & & & & \\
ROA & -0.5508 & -0.5744 & 1 & & & & \\
DIV & -0.0086 & -0.017 & -0.0275 & 1 & & & \\
CAR & -0.1968 & -0.2515 & 0.1718 & -0.0605 & 1 & & \\
TA & -0.0497 & -0.117 & 0.1111 & 0.1934 & -0.052 & 1 & \\
LB & 0.0766 & 0.0193 & -0.002 & 0.11 & -0.0961 & 0.6198 & 1 & \\
RB & -0.35 & -0.3308 & 0.3912 & -0.1207 & 0.271 & -0.5274 & 0.516 & 1 \\
\hline
\end{tabular}

\section{Regression Analysis}

Both random effect panel least square and fixed effect panel least square models were used on the observed data. Both models have the characteristics like cross-section and time-series, so both methods were adopted for this study. The approaches have the features of both modifying the time series base and analyzing the single entity.

\section{Fixed-Effect Panel Least Square Model}

The fixed effect least square model has R square amounting 0.338. Therefore, the model could interpret 33 percent of NPLs. The fixed-effect model showed that ROA negatively affected NPL, and the ROA p-value was below $1 \%$. Thus, it was statistically significant. Meanwhile, BEF was positively related to NPL with the p-value below $1 \%$, so it was also statistically significant. Furthermore, both DIV and CAR displayed negative correlations with NPLs. However, they did not have statistically significant correlations.

\section{Random-Effect Panel Least Square Model}

The random effect least square model has the $\mathrm{R}$ square amounting 0.383 . Therefore, independent variables could explain NPLs as much as 38\% (see Table 3). ROA was identified to influence negatively NPLs and statistically significant. However, bank efficiency (BEF) was identified to have positive correlation with NPLs. Both had p-values below $1 \%$. Thus, both ROA and BEF had important influence on NPLs. Also, both DIV and CAP were negatively related to NPLs. However, they were not statistically significant.

Table 3. Random Effect Panel Least Square Model

\begin{tabular}{llrrrr}
\hline & \multicolumn{2}{c}{ Unstandardized coefficient } & \\
& Model 1 & \multicolumn{1}{c}{ Standard error } & $t$-Value & Significant value \\
\hline & Constant & 0.0054 & 0.0059 & 0.91 & 0.362 \\
& BEF & 0.0002 & 0.0001 & 4.38 & 0.000 \\
& ROA & -0.0022 & 0.0004 & -4.95 & 0.000 \\
Square $=38.34)$ & -0.0027 & 0.0038 & -0.72 & 0.471 \\
& DIV & -0.0001 & 0.0001 & -0.63 & 0.531 \\
& CAR & -0.0001 & 0.0001 & -0.43 & 0.667 \\
& TA & 0.0002 & 0.0032 & 0.08 & 0.937 \\
& LB & -0.0048 & 0.0031 & -1.53 & 0.125 \\
\hline
\end{tabular}




\section{Hausman's Test}

The Hausman's test was used to choose the most suitable model between random effect and fixed effect panel least square models. The null hypothesis is a model of fixed effect panel least square model, whereas the alternative model is a model of random effects. Since the outcome indicated that the p-value was statistically insignificant, random effect model was opted as the best model.

\section{Discussion}

Our findings indicated a negative correlation between NPLs and ROA. This contradicts the study performed by Rajan (1994), which showed positive correlation between profitability and NPLs. However, the fndings are confirmed by Berger and DeYoung (1997), who claimed that profitability correlated negatively with NPLs. They concluded that as the ROA declined, the bank tended to proceed with high-risk projects, resulting in increased NPLs. This argument is also supported by Makri et al. (2014) who revealed the negative correlation between NPLs and ROA. They said that the financial performance of banks was related to the bank's risk-taking behavior. Highly profitable banks have less motivation to participate in high-risk transactions.

For the specified period, our findings suggested a positive correlation between NPLs and bank efficiency. It is supported by Benthem (2017) that agreed with "bad management" hypothesis. This hypothesis indicates that managers who get low payment will lead to poor monitoring of borrowers. Finally, banks tend to give risky credit. This hypothesis was also proven by Ekanayake and Azeez (2015) in Sri Lanka. However, this result opposes the study conducted by Berger and DeYoung (1997) that NPLs negatively affect bank efficiency.

Banking capital has a vital role in banking efficiency. The outcome of this study described that NPLs and banking capital were negatively correlated. The findings also described a negative correlation between NPLs and bank capital, which confirms the study of Rajan (1994), who believed that bank capital and NPLs negatively correlated. Based on the findings, NPLs had a negative correlation with income diversification. Ghosh (2015) confirmed that income diversification had a negative correlation with NPLs.

\section{Robustness check}

Endogeneity is one possible issue related to this study. This problem was solved by employing a two-stage least square (2 SLS) regression with instrumental variables. Following Herdhayinta and Supriyono (2019), the loan deposit ratio (LDR) and net interest margin (NIM) were employed as instrumental variables for return on asset.

Firstly, the first-stage regression was carried out to get fitted ROA. ROA was the dependent variable, while the loan deposit ratio and net interest margin were independent variables. Both loan deposit ratio and net interest margin had positive relationships with ROA and were statistically significant since their p-value was below $1 \%$. Table 4 displays the second-stage regression of NPLs with fitted ROA. The result showed that both ROA and BEF werre statistically significant and consistent with the prior findings (see Table 3).

Table 4. Second-Stage Regression of NPLs With Fitted ROA

\begin{tabular}{llrrrr}
\hline Variables & \multicolumn{1}{c}{ B } & $\begin{array}{c}\text { Standard } \\
\text { error }\end{array}$ & t-Value & \multicolumn{2}{c}{ Significant value } \\
\hline & Constant & 0.0005 & 0.0066 & 0.08 & 0.934 \\
BEF & 0.0002 & 0.00006 & 4.84 & 0.000 \\
Fitted ROA & -0.0019 & 0.0008 & -2.39 & 0.017 \\
& DIV & -0.0017 & 0.0042 & -0.41 & 0.682 \\
CAR & -0.0001 & 0.0001 & -0.71 & 0.48 \\
& TA & -0.0001 & 0.0001 & -1.66 & 0.096 \\
& LB & 0.0012 & 0.0016 & 0.73 & 0.465 \\
RB & -0.005 & 0.002 & -2.52 & 0.012 \\
\hline
\end{tabular}

\section{Conclusion}

Indonesia's banking sector must anticipate the problems of NPLs based on the financial crisis. This research main objective is to identify the bank factors that influence NPLs in Indonesia's banking industry. The findings described that bank efficiency was positively related and significant statistically to NPLs. To maintain low number of NPLs, banks must keep the operational expenses low. The random effect least square model illustrated that (ROA) profitability was negatively significant to NPLs. This means that bank profitability is heavily affected by the rise in the number of NPLs. Different factors which increase the level of NPL include political intervention in the corresponding country where the banks reside and the inappropriate investment determination by managers. Therefore, the government might support banks to get more profits in order that the banks are able to conduct appropriate credit procedures like testing the creditors' creditworthiness. Consequently, the NPL value will be 
lower, and the banks would earn more profits. In addition, bank managers must invest in valuable projects, so the risk of failure is low, and the banks can make more profit as a result. In addition, both income diversification and bank capital showed negative relationships with NPLs and were statistically insignificant.

This study focuses on limited banking factors in state-owned banks as NPL determinant during the period of 2010-2019. The future research is expected to add more banking factors and lengthen the time periods. Also, the further study can adopt private banks.

\section{References}

Ahmad, F., \& Bashir, T. (2013). Explanatory power of bank specific variables as determinants of non-performing loans: Evidence form Pakistan. World Applied Sciences Journal, 22(2), 243-255. https://doi.org/10.5829/idosi.wasj.2013.22.09.1908

Alton, R. G. and H. J. H. (2001). As Economy Flounders, Do We See A Rise in Problem Loans?No Title. In Federal Reserve Bank Journal, (Issue 142, pp. 9-15).

Alton, R. G., \& Hazen, J. H. (2001). As economy flounders, do we see a rise in problem loans. Federal Reserve Bank of St. Louis, 11(4), 45-65.

Benthem, C. S. van. (2017). The relation among non-performing loans, operating efficiency, and capitalization in commercial banking. University of Twente.

Berger, A. N., \& DeYoung, R. (1997). Problem loans and cost efficiency in commercial banks. Journal of Banking and Finance, 21(6), 849-870. https://doi.org/10.1016/S0378-4266(97)00003-4

Boudriga, A., Boulila Taktak, N., \& Jellouli, S. (2009). Banking supervision and nonperforming loans: a crosscountry analysis. In Journal of Financial Economic Policy (Vol. 1, Issue 4). https://doi.org/10.1108/17576380911050043

Daley, J., \& Matthews, K. (2009). Measuring bank efficiency: Tradition or sophistication? - A note (E2009/24; Cardiff Economics Working Papers, Issue June). https://www.econstor.eu/bitstream/10419/65842/1/613127552.pdf

Djiogap, F., \& Ngomsi, A. (2012). Determinants of bank long-term lending behavior in the Central African Economic and Monetary Community (CEMAC). Review of Economics and Finance, 2, 107-114.

Ekanayake, N., \& Azeez, A. A. (2015). Determinants of Non-performing loans in licensed commercial banks: Evidence from Sri Lanka. Asian Economic and Financial Review, 5(6), 868-882. https://doi.org/10.18488/journal.aefr/2015.5.6/102.6.868.882

Fiordelisi, F., Marques-Ibanez, D., \& Molyneux, P. (2011). Efficiency and risk in European banking. Journal of Banking and Finance, 35(5), 1315-1326. https://doi.org/10.1016/j.jbankfin.2010.10.005

Ghosh, A. (2015). Banking-industry specific and regional economic determinants of non-performing loans: Evidence from US states. Journal of Financial Stability, 20, 93-104. https://doi.org/10.1016/j.jfs.2015.08.004

Herdhayinta, H., \& Supriyono, R. A. (2019). Determinants of Bank Profitability: the Case of the Regional Development Bank (Bpd Bank) in Indonesia. Journal of Indonesian Economy and Business, 34(1), 1. https://doi.org/10.22146/jieb.17331

Hu, J. L., Li, Y., \& Chiu, Y. H. (2004). Ownership and nonperforming loans: Evidence from Taiwan's banks. Developing Economies, 42(3), 405-420. https://doi.org/10.1111/j.1746-1049.2004.tb00945.x

Ivanovic, M. (2016). Determinants of credit growth: The case of Montenegro. Journal of Central Banking Theory and Practice, 5(2), 101-118. https://doi.org/10.1515/jcbtp-2016-0013

Keeton, W. R. (1999). Does faster loan growth lead to higher loan losses? Economic Review, 84(2), 57-75.

Khan, M. A., Siddique, A., \& Sarwar, Z. (2020). Determinants of non-performing loans in the banking sector in developing state. Asian Journal of Accounting Research, 5(1), 135-145. https://doi.org/10.1108/ajar-102019-0080

Koju, L., Koju, R., \& Wang, S. (2018). Macroeconomic and bank-specific determinants of non-performing loans: Evidence from Nepalese banking system. Journal of Central Banking Theory and Practice, 7(3), 111-138. https://doi.org/10.2478/jcbtp-2018-0026

Kumar, V., \& Kishore, M. P. (2019). Macroeconomic and bank specific determinants of non-performing loans in 
UAE conventional bank. Journal of Banking and Finance Management, 2(1), 1-12.

Louzis, D. P., Vouldis, A. T., \& Metaxas, V. L. (2012). Macroeconomic and bank-specific determinants of nonperforming loans in Greece: A comparative study of mortgage, business and consumer loan portfolios. Journal of Banking and Finance, 36(4), 1012-1027. https://doi.org/10.1016/j.jbankfin.2011.10.012

Makri, V., Tsagkanos, A., \& Bellas, A. (2014). Determinants of non-performing loans: The case of Eurozone. Panoeconomicus, 61(2), 193-206. https://doi.org/10.2298/PAN1402193M

Mensah, F. A., \& Adjei, A. B. (2015). Determinants of non-performing loans in Ghana banking industry. International Journal of Computational Economics and Econometrics, 5(1), 35-54. https://doi.org/10.1504/ijcee.2015.066207

Michael, J. N., Vassanthi, G., \& Selvaraju, R. (2006). Effect of non-performing assets on operational efficiency of central co- operative banks. Indian Economic Panorama, 16(3), 33-39.

Nkusu, M. (2011). Nonperforming loans and macrofinancial vulnerabilities in advanced economies. In IMF Working Papers (Vol. 11, Issue 161). https://doi.org/10.5089/9781455297740.001

Prasanna, P. K., Thenmozhi, M., \& Rana, N. (2014). Determinants of non-performing advances in Indian banking system. Banks and Bank Systems, 9(2), 65-77.

Prasanto, O., Wulandari, D., Narmaditya, B. S., \& Kamaludin, M. (2020). Determinants of bank profitability: A new evidence from state-owned banks in Indonesia. Trikonomika, 19(1), 29-35. https://doi.org/10.23969/trikonomika.v19i1.1443

Rachman, R. A., Kadarusman, Y. B., Anggriono, K., \& Setiadi, R. (2018). Bank-specific factors affecting nonperforming loans in developing countries: Case study of Indonesia. Journal of Asian Finance, Economics and Business, 5(2), 35-42. https://doi.org/10.13106/jafeb.2018.vol5.no2.35

Rajan, R. (1994). Why bank credit policies fluctuate: A theory and some evidence. The Quarterly Journal of Economics, 2(109), 399-441.

Soedarmono, W., Machrouh, F., \& Tarazi, A. (2011). Bank market power, economic growth and financial stability: Evidence from Asian banks. Journal of Asian Economics, 22(6), 460-470. https://doi.org/10.1016/j.asieco.2011.08.003

Souza, G. J. de G. e, \& Feijó, C. A. (2011). Credit risk and macroeconomic interactions: Empirical evidence from the Brazilian banking system. Modern Economy, 2(5), 910-929. https://doi.org/10.4236/me.2011.25102

Stijepović, R. (2014). Recovery and reduction of non-performing loans - Podgorica Approach. Journal of Central Banking Theory and Practice, 3(3), 101-118. https://doi.org/10.2478/jcbtp-2014-0017

Tanda, A. (2015). The effects of bank regulation on the relationship between capital and risk. Comparative Economic Studies, 57(1), 31-54. https://doi.org/10.1057/ces.2014.35

Vouldis, A. T., \& Louzis, D. P. (2018). Leading indicators of non-performing loans in Greece: the information content of macro-, micro- and bank-specific variables. Empirical Economics, 54(3), 1187-1214. https://doi.org/10.1007/s00181-017-1247-0 